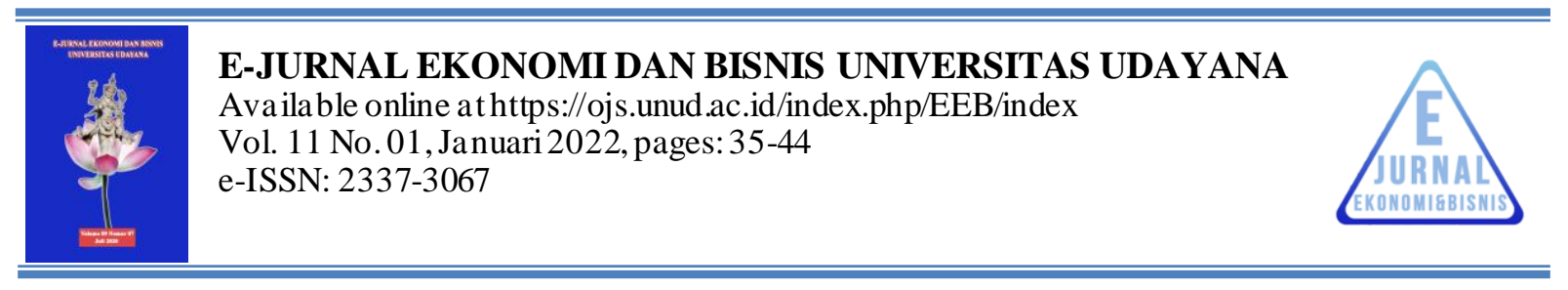

\title{
PENGARUH REMITANSI, FOREIGN DIRECT INVESTMENT, DAN INFLASI TERHADAP PERTUMBUHAN EKONOMI INDONESIA
}

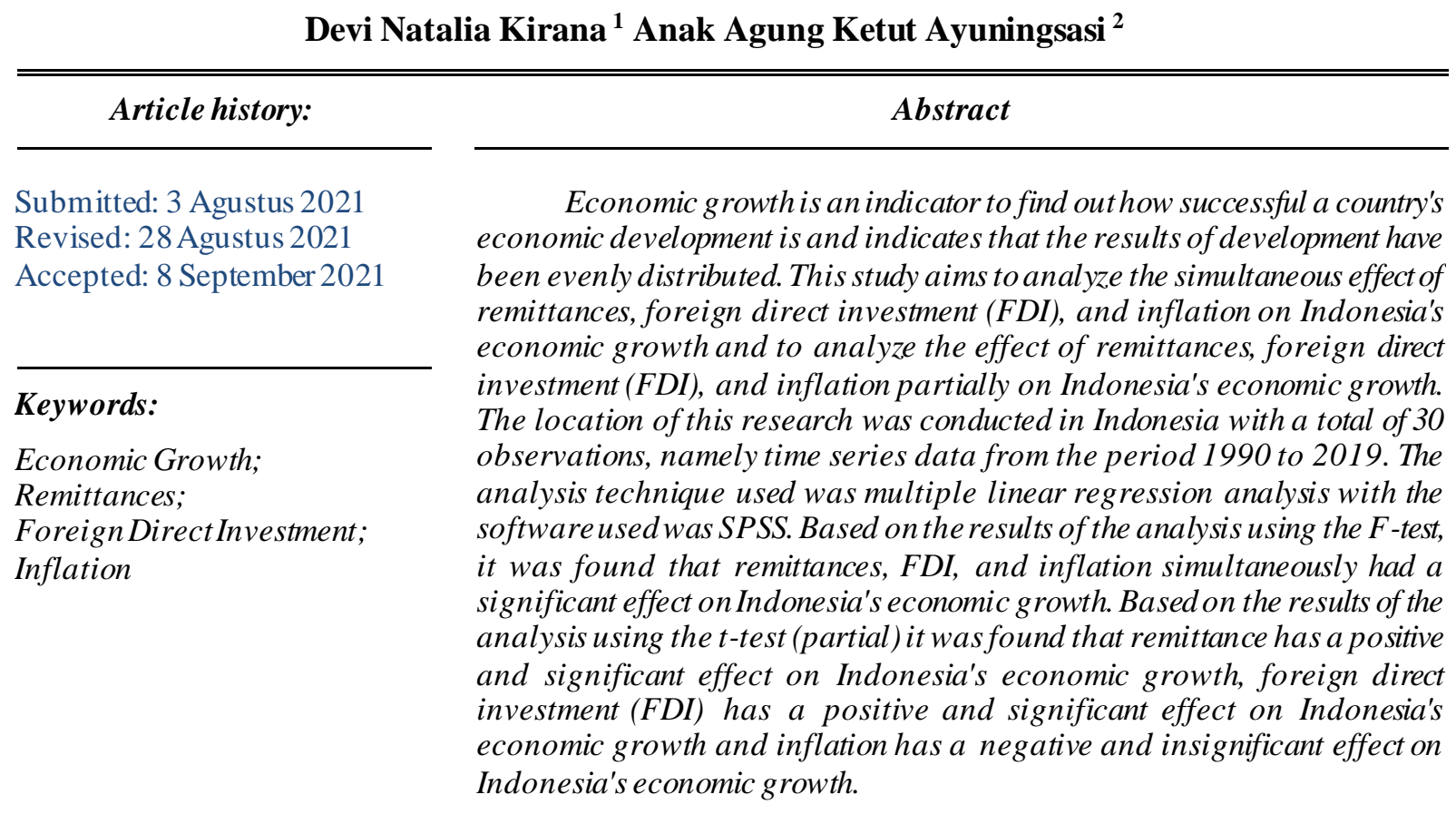

\section{Kata Kunci:}

Abstrak

Pertumbuhan Ekonomi; Remitansi; Investasi Asing Langsung; Infla si;

Koresponding:
Fakulas Ekonomi dan Bisnis
Universitas Udayana, Bali,
Indonesia
Email:
devikiranaaa25@gmail.com

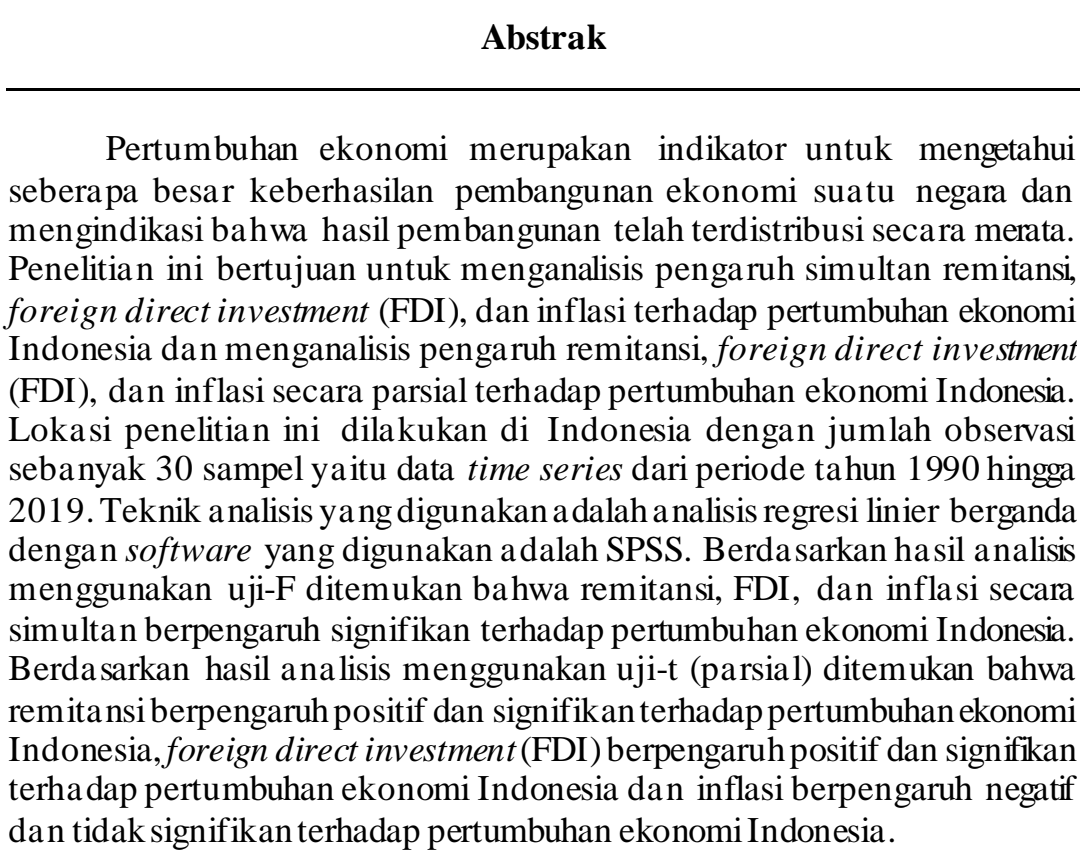

Fakultas Ekonomidan Bisnis Universitas Udayana, Ba li, Indonesia ${ }^{2}$ 


\section{PENDAHULUAN}

Umumnya suatu negara melakukan pembangunan nasional dengan tujuan untuk menciptakan kesejahteraan masyarakatnya, dimana keberhasilan pembangunan tersebut terlihat pada pertumbuhan ekonomi negara itu sendiri. Sebagai salah satu indikator keberhasilan pembangunan, tingkat pertumbuhan ekonomi pada suatu negara dapat menunjukkan bahwa dengan tingginya angka pertumbuhan ekonomi maka tingkat kesejahteraan masyarakat juga akan meningkat (Dama dkk, 2016). Menurut Kurniawan dan Managi (2018), adanya peningkatan pertumbuhan ekonomi akan mempengaruhi peningkatan kesejahteraan dan IPM (Indeks Perkembangan Manusia). Dalam teori ekonomi aliran Klasik, disebutkan bahwa tingginya pertumbuhan ekonomi negara menunjukkan bahwa kinerja ekonomi negara tersebut stabil, sedangkan apabila pertumbuhan ekonomi negara rendah dan cenderung negatif menunjukkan bahwa ekonomi negara tersebut sedang memburuk (Azoulay, 2020).

Pertumbuhan ekonomi pada suatu negara dinilai berkualitas jika pertumbuhan tersebut sejalan dengan menurunnya pengangguran, kemiskinan dan semakin meratanya distribusi pendapatan diantara penduduk (Rimbawan, 2012). Dalam analisis makro, pertumbuhan ekonomi yang dicapai oleh satu negara diukur dari perimbangan pendapatan nasional riil yang dicapai oleh suatu negara (Dewi dkk., 2013). Pertumbuhan ekonomi didefinisikan sebagai kenaikan pendapatan nasional negara dari tahun ke tahun yang diukur melalui produk domestik bruto (PDB). Mankiw (2014) menyebutkan bahwa pendapatan nasional yang diukur dengan Produk Domestik Bruto (PDB) merupakan nilai pasar barang dan jasa akhir yang diproduksi dalam perekonomian dalam kurun waktu tertentu.

Berdasarkan data yang diperoleh dari Badan Pusat Statistik (2020) diperoleh informasi mengenai perkembangan PDB Indonesia dari tahun 2014-2019 yang menunjukkan bahwa PDB Indonesia mengalami fluktuasi tiap tahunnya. Bank Indonesia (2020) dalam laporan tahunannya menyebutkan penurunan dan peningkatan PDB sejalan dengan kegiatan ekspor, ketika kegiatan ekspor melemah maka PDB Indonesia ikut menurun dan sebaliknya ketika kegiatan ekspor Indonesia meningkat maka PDB juga meningkat.

Kondisi perekonomian dalam negeri yang berfluktuatif mengakibatkan meningkatnya arus migrasi pekerja ke luar negeri untuk mencari kesempatan bekerja yang lebih baik. Fenomena migrasi internasional pada tenaga kerja terjadi dan berkembang seiring dengan pola hubungan yang terjalin antar negara. Meningkatnya hubungan antar negara akan berpengaruh pada intensitas arus migrasi dari dan ke negara bersangkutan. Peningkatan jumlah pekerja migran untuk bekerja di luar negeri merupakan salah satu indikator dari globalisasi atau integrasi internasional.

Berdasarkan data pada Badan Perlindungan Pekerja Migran (BP2MI, 2020) diketahui bahwa pengiriman pekerja migran Indonesia (PMI) ke luar negeri terus mengalami penurunan. Pada tahun 2014, jumlah PMI sebanyak 429.874 orang dan mengalami penurunan drastis pada tahun 2016 menjadi 234.451 orang. Jumlah PMI kembali mengalami peningkatan pada tahun-tahun berikutnya dan yang tercatat terakhir pada tahun 2019 adalah sebanyak 276.552 orang. Salah satu faktor penyebab menurunnya jumlah PMI adalah adanya aturan yang ketat di tingkat nasional dan daerah seperti diberlakukannya moratorium pengiriman PMI sejak tahun 2015. Presiden Jokowi menetapkan kebijakan berupa penghentian pengiriman dan penempatan PMI pada sektor domestik ke 19 negara di kawasan Timur Tengah (termasuk Arab Saudi), melalui Keputusan Menteri Tenaga Kerja Nomor 260 Tahun 2015 tentang penghentian dan pelarangan penempatan TKI pada pengguna perseorangan di negara-negara kawasan Timur Tengah (Menteri Ketenagakerjaan Republik Indonesia, 2015).

Kebijakan moratorium penempatan pekerja migran atau tenaga kerja Indonesia terjadi karena belum adanya regulasi mengenai perlindungan pekerja migran di negara penempatan. Sebenarnya hal tersebut juga termasuk bentuk dari melindungi pekerja migran Indonesia dari risiko di negara tujuan atau penempatan.

Pengaruh Remitansi, Foreign Direct Investment, dan Inflasi Terhadap Pertumbuhan Ekonomi Indonesia, Devi Natalia Kirana dan Anak Agung Ketut Ayuningsasi 
Umumnya PMI yang bekerja di luar negeri dilatarbelakangi oleh dorongan ekonomi, dimana pemikiran para PMI bermuara pada jumlah remitansi yang dapat diterima. Alasan utama para PMI bekerja keluar negeri karena remitansi yang diterima pada umumnya cukup besar apabila dibandingkan dengan bekerja di dalam negeri. Remitansi menurut World Bank dalam Sihombing dan Safaruddin (2007), adalah pembayaran antar negara dari orang ke orang dengan besaran nilai yang secara relatif kecil, transferan uang kiriman tersebut dilakukan oleh para pekerja asing secara berulang kepada keluarga di daerah asal.

Salah satu faktor eksternal yang dapat memberi pengaruh terhadap pertumbuhan ekonomi adalah remitansi (Handley et.al, 2020). Menurut Barajas (2009), faktor eksternal seperti remitansi pada suatu negara sama pentingnya seperti faktor internal suatu negara dalam meningkatkan pertumbuhan ekonomi, khususnya di negara berkembang (Barajas, 2009). Pada Neraca Pembayaran Indonesia (NPI), inflows remitansi tersebut memberikan kontribusi 27 persen dari keseluruhan nilai services, income, dan current transfer. Akan tetapi, remitansi juga dapat memberikan dampak negatif dengan menurunkan upaya kerja dan pada jangka panjang dapat menurunkan pertumbuhan ekonomi (Pardede dan Setyari, 2016). Chami et al. (2009), Handoyo et al. (2020), dan Dwi Kurniawan (2020) menemukan bahwa remitansi memiliki pengaruh negatif dan signifikan terhadap pertumbuhan ekonomi. Hal ini dikarenakan penerimaan remitansi tidak digunakan untuk pengeluaran yang produktif atau sebagai modal kerja, melainkan untuk konsumsi belaka.

Faktor kedua yang dapat memengaruhi pertumbuhan ekonomi adalah investasi. Investasi yang semakin stabil akan membantu menjaga kestabilan laju pertumbuhan ekonomi negara yang bersangkutan (Sulistiawati, 2012). Teori pertumbuhan ekonomi menurut Harrod-Domar menyebutkan bahwa untuk meningkatkan petumbuhan ekonomi, maka suatu perekonomian harus menabung dan menginvestasikan suatu proporsi tertentu dari output totalnya. Hal ini berarti apabila suatu negara ingin meningkatkan pertumbuhan ekonominya, maka negara tersebut harus berani berinvestasi. Semakin banyak investasi yang dimiliki, maka semakin cepat pula perekonomian akan meningkat (Arsyad, 2004).

Investasi asing langsung memiliki peranan yang besar bagi Indonesia dalam melengkapi kebutuhan investasi dalam negeri. Investasi asing langsung dapat meningkatkan kemampuan produksi dan menjadi media transfer teknologi dari luar negeri ke dalam negeri (Liu \& Su, 2016). Menurut Susic et al. (2017), penanaman modal asing memberikan dampak positif terhadap perekonomian negara tuan rumah karena melalui penanaman modal asing bisa menambah ketersediaan dana bagi negara tersebut (recipient country). Berdasarkan informasi yang diperoleh dari Worldbank (2020) diketahui bahwa pertumbuhan investasi asing langsung (foreign direct investment/FDI) Indonesia beberapa tahun belakangan mengalami pertumbuhan yang positif, meskipun sempat mengalami penurunan tajam pada tahun 2016 yang disebabkan oleh kerapuhan ekonomi global, pertumbuhan lamban di beberapa negara pengekspor komoditas dan kemerosotan keuntungan beberapa perusahaan multinasional pada tahun 2015.

Faktor ketiga yang dapat mempengaruhi pertumbuhan ekonomi adalah inflasi. Inflasi merupakan salah satu indikator yang mengukur stabilitas perekonomian negara. Engla (2013) menyebutkan inflasi dalam perspektif ekonomi sebagai fenomena moneter dimana ketika terjadi fluktuasi akan mengakibatkan gejolak ekonomi. Sukirno (2011) mendefinisikan inflasi sebagai fenomena terjadinya kenaikan harga barang secara terus menerus, yang kemudian akan berdampak pada penurunan daya beli masyarakat karena nilai riil dari pada mata uang yang pada akhirnya akan menyebabkan pertumbuhan ekonomi melambat (Ningsih \& Andiny, 2018). Dapat dikatakan bahwa apabila inflasi tidak dapat dikontrol, maka akan mempengaruhi pertumbuhan ekonomi.

Pengaruh Remitansi, Foreign Direct Investment, dan Inflasi Terhadap Pertumbuhan Ekonomi Indonesia, Devi Natalia Kirana dan Anak Agung Ketut Ayuningsasi 
Kasidi (2013) menyatakan bahwa inflasi memberi pengaruh negatif terhadap pertumbuhan ekonomi suatu negara. Penelitian yang dilakukan oleh Madurapperuma (2016) juga menunjukkan bahwa inflasi berpengaruh negatif dan signifikan terhadap pertumbuhan ekonomi di Sri Lanka. Bick (2010) menemukan bahwa terjadi hubungan yang signifikan antara inflasi dengan pertumbuhan ekonomi. Inflasi terjadi ketika tingkat harga umum naik dan kenaikan harga ini bisa berdampak buruk pada kegiatan produksi karena ketika biaya produksi naik menyebabkan kegiatan investasi beralih pada kegiatan yang kurang mendorong produk nasional, investasi produktif berkurang, dan kegiatan ekonomi menurun.

Apabila dicermati kondisi inflasi di Indonesia pada beberapa tahun terakhir, angka inflasi ini cenderung berfluktuasi. Pada tahun 2013 inflasi di Indonesia mencapai 6,4 persen kemudian menurun cukup signifikan pada tahun 2016 yaitu mencapai 3,5 persen dan pada tahun 2019 mencapai 3 persen. Inflasi yang sebelumnya di tahun 2012 mengalami penurunan namun pada tahun 2013 mengalami peningkatan dikarenakan kenaikan harga BBM bersubsidi sebagai salah satu faktor penyumbang terbesar selain tarif angkutan dalam kota dan bawang merah.

Berdasarkan rumusan masalah dan pembahasan hasil penelitian terlebih dahulu maka diajukan hipotesis sebagai berikut: H1: Variabel remitansi, Foreign Direct Investment (FDI), dan inflasi berpengaruh secara simultan terhadap pertumbuhan ekonomi di Indonesia. H2: Variabel remitansi dan Foreign Direct Investment (FDI) secara parsial berpengaruh positif terhadap pertumbuhan ekonomi di Indonesia. H3: Variabel inflasi berpengaruh negatif terhadap pertumbuhan ekonomi di Indonesia.

\section{METODE PENELITIAN}

Penelitian ini bertujuan untuk mengetahui pengaruh remitansi, Foreign Direct Investment (FDI), dan inflasi terhadap pertumbuhan ekonomi Indonesia. Jenis data yang digunakan dalam penelitian yaitu data kuantitatif berupa data GDP di Indonesia, remitansi, FDI, dan inflasi. Berdasarkan sumbernya, data yang digunakan dalam penelitian ini adalah data sekunder yang diperoleh dari World Bank, Laporan Data Tahunan BI, dan BPS. Metode pengumpulan data yang digunakan yaitu metode observasi dengan melakukan pengamatan dan mencatat informasi penting yang berkaitan dengan penelitian. Data penelitian dianalisis dengan menggunakan teknik analisis regresi linier berganda dan dilakukan pra-analisis dengan pengujian asumsi klasik untuk mengetahui bahwa model regresi yang dianalisis memiliki data yang terdistribusi normal, bebas dari gejala multikolinieritas, autokorelasi, dan heteroskedastisitas.

\section{HASIL DAN PEMBAHASAN}

Berdasarkan data dari Worldbank (2020) diketahui perkembangan pertumbuhan ekonomi Indonesia dari tahun 1990 sampai tahun 2019 cenderung mengalami fluktuasi yang dikarenakan adanya proses pembangunan. Secara umum terlihat GDP Indonesia mengalami tren yang semakin meningkat, namun terjadinya krisis moneter pada tahun 1997 menyebabkan pertumbuhan ekonomi di Indonesia cenderung menurun sebesar 4,70 persen. Dampak dari krisis menyebabkan tingkat pertumbuhan ekonomi tahun berikutnya yaitu pada tahun 1998 mengalami penurunan yang sangat drastis yaitu sebesar -13,13 persen. Pada tahun 1999, pertumbuhan ekonomi kembali meningkat walaupun pertumbuhan ekonomi masih rendah dibanding dengan tahun 1997. Lambat laun perekonomian di Indonesia mulai membaik dan mengalami peningkatan pada tahun 2000 sebesar 4,92 persen. Pada tahun berikutnya sampai dengan tahun 2013 pertumbuhan ekonomi cenderung terus

Pengaruh Remitansi, Foreign Direct Investment, dan Inflasi Terhadap Pertumbuhan Ekonomi Indonesia, Devi Natalia Kirana dan Anak Agung Ketut Ayuningsasi 
meningkat. Pertumbuhan ekonomi Indonesia sejak 2014 hingga 2019 tidak sesuai target yang ditetapkan APBN dan terendah pada tahun 2015. Beberapa penyebab penurunan ini diantaranya adalah kondisi global yang menjadi sumber perlambatan pertumbuhan ekonomi yaitu perang dagang AS dan Tiongkok, Kondisi geopolitik di Timur Tengah, serta proses keluarnya Brexit serta dampak virus corona yang terjadi pada akhir tahun 2019 di China.

Berdasarkan data dari Worldbank (2020) diketahui bahwa pada tahun 1990 hingga 2019 penerimaan remitansi Indonesia mengalami fluktuasi, namun cenderung meningkat. Penerimaan remitansi terendah terjadi pada tahun 1991 dan tertinggi pada tahun 2019. Pada tahun 1998, terjadi peningkatan remitansi yang disebabkan oleh jumlah TKI yang meningkat secara signifikan seiring dengan terjadinya krisis ekonomi di Indonesia. Pada tahun 2005, peningkatan remitansi disebabkan oleh berlakunya Undang-Undang No. 39 Tahun 2004 tentang penempatan dan perlindungan TKI di luar negeri. Sejak berlakunya UU tersebut, penerimaan remitansi secara nominal meningkat cukup signifikan. Pada tahun berikutnya, penerimaan remitansi semakin meningkat seiring dengan membaiknya perekonomian Indonesia yang ditunjukkan oleh semakin meningkatnya PDB yang dihasilkan oleh Indonesia.

Jumlah remitansi terbesar diperoleh oleh pekerja migran Indonesia dari negara-negara ASEAN seperti Malaysia, Singapura, Brunei Darussalam, yakni sebesar 35 persen dari total remitansi Indonesia. Sementara itu, negara-negara di Timur Tengah menjadi pengirim remitansi terbanyak kedua setelah ASEAN sebesar 34 persen yang selanjutnya diikuti negara-negara Asia bukan ASEAN sebesar 19 persen. Hal ini dapat disebabkan banyaknya tenaga kerja Indonesia yang bekerja di beberapa negara tersebut mengingat negara tersebut membutuhkan tenaga kerja low skill dengan upah rendah, sehingga tidak heran jika kontribusi penerimaan remitansi terhadap devisa terus mengalami kenaikan tiap tahunnya.

Berdasarkan data dari Worldbank (2020) diketahui perkembangan Foreign Direct Investment Indonesia meningkat pada dasawarsa 1990-an. Investasi di Indonesia menunjukkan angka negatif pada tahun 1998 sampai dengan 2001 karena adanya krisis ekonomi pada tahun 1997 yang menyebabkan terjadinya penurunan investasi. Kondisi ini mulai membaik sejak tahun 2000 terutama setelah desentralisasi fiskal diterapkan di Indonesia pada tahun 1999. Berbagai insentif yang diberikan oleh pemerintah daerah menyebabkan kenaikan investasi asing langsung secara signifikan. Kenaikan signifikan investasi asing ini dapat dilihat dari tahun 1998-2001 yang terus-menerus menunjukkan angka negatif kemudian pada tahun 2004 ke atas terus mengalami peningkatan hingga tahun 2019.

Berdasarkan data dari Badan Pusat Statistik (2020) diketahui bahwa inflasi di Indonesia mengalami fluktuasi. Kecenderungan yang terjadi yaitu adanya krisis menyebabkan penurunan pertumbuhan ekonomi negara disertai dengan peningkatan inflasi. Menjelang akhir pemerintahan Orde Baru (sebelum krisis moneter) angka inflasi tahunan dapat ditekan sampai pada single digit, tetapi secara umum masih mengandung kerawanan jika dilihat dari seberapa besar prosentase kelompok masyarakat golongan miskin yang menderita akibat inflasi. Lebih-lebih setelah semakin berlanjutnya krisis moneter yang kemudian diikuti oleh krisis ekonomi, yang menjadi salah satu dari penyebab jatuhnya pemerintahan Orde Baru, angka inflasi cenderung meningkat pesat (mencapai lebih dari 75 persen pada tahun 1998), namun pada sepuluh tahun terakhir ini inflasi terlihat tinggi hingga tahun 2015. Inflasi yang sebelumnya di tahun 2012 mengalami penurunan, namun sejak tahun 2013 hingga 2015 inflasi mengalami peningkatan menjadi 6,4 persen yang dikarenakan kenaikan harga BBM bersubsidi. Pada tahun 2016 hingga 2019 inflasi terhitung rendah di angka 3 persen menurut Bank Indonesia hal ini disebabkan meningkatnya permintaan masyarakat diimbangi dengan suplai barang-barang produksi yang9 mencukupi dan nilai kurs yang terkendali.

Pengaruh Remitansi, Foreign Direct Investment, dan Inflasi Terhadap Pertumbuhan Ekonomi Indonesia, Devi Natalia Kirana dan Anak Agung Ketut Ayuningsasi 
Berdasarkan analisis regresi linear berganda, diperoleh persamaan dalam penelitian ini sebagai berikut.

$$
\mathrm{Y}=11,673+0,199 \mathrm{X}_{1}+1,334 \mathrm{X}_{2}-0,002 \mathrm{X}_{3}
$$

Pengujian asumsi klasik yang dilakukan memperoleh hasil Kolmogorov-Smirnov Test (K-S) nilai statistik sebesar 0,110 dengan derajat probabilitas signifikansi 0,200 yang lebih besar dari 0,05 sehingga terpenuhi asumsi normalitas dalam penelitian ini. Hasil uji multikolinearitas menunjukkan bahwa nilai tolerance lebih dari 0,10 dan nilai VIF lebih rendah dari 10 maka dapat disimpulkan bahwa tidak ada multikolinieritas antar variabel independen dalam model regresi ini. Pengujian autokorelasi menunjukkan nilai Durbin-Watson test berada diantara -2 sampai dengan $+2=-2<0,737<2$, sehingga dapat disimpulkan bahwa tidak ada autokorelasi dalam model regresi. Pengujian heteroskedastisitas dengan uji Glejser menunjukkan bahwa nilai probabilitas signifikansi di atas 0,05 atau di atas tingkat kesalahan 5 persen, sehingga dapat disimpulkan dalam model regresi tidak mengandung adanya heteroskedastisitas.

Berdasarkan hasil uji F, diketahui bahwa $F_{\text {hitung }}=117,122$ dan $F_{\text {tabel }}=2,98$ oleh karena $F_{\text {hitung }}>$ $\mathrm{F}_{\text {tabel }}$ yang mengindikasikan bahwa remitansi $\left(\mathrm{X}_{1}\right)$, FDI $\left(\mathrm{X}_{2}\right)$, dan inflasi $\left(\mathrm{X}_{3}\right)$ secara simultan berpengaruh signifikan terhadap pertumbuhan ekonomi Indonesia $(\mathrm{Y})$. Hal ini juga didukung oleh nilai $R$ Square yakni sebesar 0,931 yang berarti bahwa variabel remitansi $\left(\mathrm{X}_{1}\right)$, FDI $\left(\mathrm{X}_{2}\right)$, dan inflasi $\left(\mathrm{X}_{3}\right)$ dapat menjelaskan variasi variabel pertumbuhan ekonomi (Y) sebesar 93,1 persen dan hanya 6,9 persen dipengaruhi oleh variabel lain yang tidak dimasukkan ke dalam penelitian.

Untuk melihat seberapa besar pengaruh variabel bebas yaitu remitansi $\left(\mathrm{X}_{1}\right), \mathrm{FDI}\left(\mathrm{X}_{2}\right)$, dan inflasi $\left(\mathrm{X}_{3}\right)$ secara parsial terhadap variabel terikat yaitu pertumbuhan ekonomi Indonesia (Y) dapat diketahui dari besarnya nilai koefisien regresi masing-masing variabel bebas. Hasil dari pengujian parsial dari penelitian ini dapat dilihat pada Tabel 1 .

Tabel 1.

Hasil Uji Pengaruh secara Parsial (Uji t)

\begin{tabular}{lccccc}
\hline \multicolumn{1}{c}{ B } & Std. Error & Beta & & t & Sig. \\
\hline (Constant) & 11,673 & 0,149 & & 78,515 & 0,000 \\
Remitansi & 0,199 & 0,021 & 0,701 & 9,436 & 0,000 \\
FDI & 1,334 & 0,000 & 0,312 & 4,151 & 0,000 \\
Inflasi & $-0,002$ & 0,002 & $-0,054$ & $-1,020$ & 0,317 \\
\hline
\end{tabular}

Sumber: Data Sekunder Diolah, 2020

Berdasarkan hasil pengujian diketahui bahwa nilai signifikansi untuk pengaruh $\mathrm{X}_{1}$ terhadap $\mathrm{Y}$ sebesar $0,000<0,05$ dan nilai thitung $9,436>t_{\text {tabel }} 2,056$, artinya remitansi $\left(X_{1}\right)$ berpengaruh positif dan signifikan terhadap pertumbuhan ekonomi Indonesia $(\mathrm{Y})$. Koefisien variabel remitansi $\left(\mathrm{X}_{1}\right)$ sebesar 0,199 artinya jika variabel independen lain nilainya tetap dan remitansi mengalami kenaikan 1 juta USD, maka pertumbuhan ekonomi Indonesia yang ditunjukkan oleh GDP harga konstan akan mengalami peningkatan sebesar 0,199 juta USD. Hasil dari penelitian ini didukung oleh penelitian yang dilakukan oleh Prabowo (2018) mengenai dampak remitansi tenaga kerja terhadap pertumbuhan ekonomi di Indonesia, yang menemukan bahwa remitansi berpengaruh positif terhadap pertumbuhan ekonomi. Selain itu, hasil penelitian ini mendukung studi empiris oleh Meyer\& Shera (2016) yang menemukan

Pengaruh Remitansi, Foreign Direct Investment, dan Inflasi Terhadap Pertumbuhan Ekonomi Indonesia, Devi Natalia Kirana dan Anak Agung Ketut Ayuningsasi 
bahwa remitansi berpengaruh positif terhadap pertumbuhan ekonomi dimana remitansi yang dihasilkan oleh para migran berpotensi untuk meningkatkan pendapatan negara dan dapat meningkatkan pembangunan sektor keuangan, sehingga dapat merangsang pertumbuhan ekonomi.

Berdasarkan hasil pengujian diketahui bahwa nilai signifikansi untuk pengaruh $\mathrm{X}_{2}$ terhadap $\mathrm{Y}$ sebesar $0,000<0,05$ dan nilai $t_{\text {hitung }} 4,151>t_{\text {tabel }} 2,056$, artinya FDI $\left(\mathrm{X}_{2}\right)$ berpengaruh positif dan signifikan terhadap pertumbuhan ekonomi Indonesia (Y). Koefisien variabel FDI $\left(\mathrm{X}_{2}\right)$ sebesar 1,334 artinya jika variabel independen lain nilainya tetap dan FDI mengalami kenaikan 1 juta USD, maka pertumbuhan ekonomi Indonesia yang ditunjukkan oleh GDP harga konstan akan mengalami peningkatan sebesar 1,334 juta USD. Hasil dari penelitian ini mendukung penelitian oleh Bagaskara Prawira (2019) mengenai pengaruh Foreign Direct Investment (FDI), ekspor, dan impor terhadap pertumbuhan ekonomi Indonesia 1998-2017 dimana FDI berpengaruh secara positif dan signifikan terhadap pertumbuhan ekonomi. Hal ini selaras dengan teori Klasik yang dikemukakan oleh Adam Smith yang menyatakan bahwa ada tiga faktor penentu pertumbuhan ekonomi yaitu sumber daya alam, sumberdaya manusia, dan barang modal. Foreign Direct Investment (FDI) termasuk investasi barang modal, karena FDI merupakan investasi riil dalam bentuk pendirian perusahaan, pembentukan pabrik, pembelian barang modal, tanah, bahan baku dan pengontrolan penanaman modal tersebut, sehingga FDI mampu mendorong peningkatan pertumbuhan ekonomi. Ini berarti tanpa adanya FDI di Indonesia, maka kegiatan ekonomi bisa berjalan lambat ataupun kurang produktif karena modal dan prasarana yang kurang mendukung.

Berdasarkan hasil pengujian dapat dilihat bahwa nilai signifikansi untuk pengaruh $\mathrm{X}_{3}$ terhadap $\mathrm{Y}$ sebesar $0,317>0,05$ dan nilai thitung $-1,020<t_{\text {tabel }} 2,056$, artinya inflasi $\left(\mathrm{X}_{3}\right)$ tidak berpengaruh signifikan terhadap pertumbuhan ekonomi Indonesia (Y). Dalam penelitian ini, inflasi yang terjadi di bawah 10 persen, sehingga inflasi tidak mampu mempengaruhi pertumbuhan ekonomi secara signifikan padahal dalam teori ekonomi, inflasi mempengaruhi pertumbuhan ekonomi. Hasil dari penelitian ini sesuai dengan penelitian sebelumnya yang dilakukan oleh Luthfi Multazam Khaironi (2019) mengenai pengaruh pengangguran dan inflasi terhadap pertumbuhan ekonomi dimana inflasi tidak berpengaruh signifikan terhadap pertumbuhan ekonomi.

Secara teoritis, penelitian ini dapat mengaplikasikan teori yang ada dan hasil penelitian menujukkan bahwa variabel remitansi berpengaruh positif dan signifikan terhadap pertumbuhan ekonomi di Indonesia. Hal ini sesuai dengan konsep remitansi dimana remitansi dikatakan sebagai suatu instrumen dalam memperbaiki keseimbangan pembayaran, serta merangsang tabungan dan investasi di daerah asal. Hasil dari penelitian ini menunjukkan bahwa variabel FDI berpengaruh positif dan signifikan terhadap pertumbuhan ekonomi di Indonesia. Hal ini sesuai dengan tujuan penanaman modal asing Indonesia yang diatur dalam Undang-Undang Nomor 25 Tahun 2007 yaitu salah satunya untuk meningkatkan pertumbuhan ekonomi nasional. Selain itu juga, dalam teori klasik pertumbuhan ekonomi, modal merupakan faktor utama pendorong pertumbuhan ekonomi. Dalam perkembangannya, modal yang digunakan suatu negara untuk mendorong pertumbuhan ekonomi tidak hanya dari modal dalam negeri, tetapi juga dari modal yang dibawa oleh negara asing. Hasil dari penelitian ini menunjukkan bahwa variabel inflasi berpengaruh negatif tetapi tidak signifikan terhadap pertumbuhan ekonomi di Indonesia. Hubungan kedua variabel ini sudah sesuai dengan teori yang menjelaskan bahwa inflasi memiliki dampak negatif terhadap perekonomian, walaupun pengaruhnya tidak signifikan.

Secara empiris,pengaruh positif remitansi terhadap pertumbuhan ekonomi mengindikasikan bahwa remitansi mempunyai peran terhadap pertumbuhan perekonomian di Indonesia karena remitansi merupakan sumber devisa. Semakin tinggi jumlah remitansi, maka devisa akan meningkat sehingga dana yang digunakan dalam pembangunan nasional juga mampu meningkat dan apabila hasil pembangunan dapat terdistribusi secara merata maka pertumbuhan ekonomi dapat meningkat. Hasil dari penelitian ini menunjukkan bahwa variabel FDI berpengaruh positif dan signifikan terhadap

Pengaruh Remitansi, Foreign Direct Investment, dan Inflasi Terhadap Pertumbuhan Ekonomi Indonesia, Devi Natalia Kirana dan Anak Agung Ketut Ayuningsasi 
pertumbuhan ekonomi di Indonesia. Setiap negara membutuhkan modal untuk membiayai proyek pembangunannya, termasuk di Indonesia. Apabila persediaan tabungan di dalam negeri tidak tercukupi, maka salah satu cara untuk mendapatkan suntikan modal adalah dengan menarik investasi secara langsung. Hasil dari penelitian ini menunjukkan bahwa variabel inflasi berpengaruh negatif tetapi tidak signifikan terhadap pertumbuhan ekonomi di Indonesia. Inflasi yang rendah dan stabil mendorong pertumbuhan ekonomi dan sebaliknya. Pada saat terjadi inflasi, produsen akan terdorong untuk memproduksi lebih banyak barang yang akan meningkatkan penghasilan produsen, terutama produsen kebutuhan pokok yang barangnya akan tetap dibeli meskipun harga barang naik.

\section{SIMPULAN DAN SARAN}

Berdasarkan hasil analisis dan pembahasan yang telah diuraikan sebelumnya, maka dapat ditarik kesimpulan bahwa secara simultan variabel remitansi, FDI, dan inflasi berpengaruh signifikan terhadap pertumbuhan ekonomi Indonesia pada tahun 1990-2019. Variabel remitansi berpengaruh positif dan signifikan terhadap pertumbuhan ekonomi Indonesia tahun 1990-2019. Variabel FDI berpengaruh positif dan signifikan terhadap pertumbuhan ekonomi Indonesia tahun 1990-2019. Variabel inflasi berpengaruh negatif tetapi tidak signifikan terhadap pertumbuhan ekonomi Indonesia tahun 19902019.

Berdasarkan hasil penelitian dan simpulan di atas, maka dapat diajukan saran bahwa remitansi menjadi salah satu faktor yang dapat meningkatkan pertumbuhan ekonomi di Indonesia. Permasalahan yang dihadapi terkait hal ini adalah rendahnya kualitas PMI sehingga pemerintah perlu untuk meningkatkan kualitas tenaga kerja Indonesia, melalui pendidikan maupun dengan cara memberikan sosialisasi mengenai pemanfaatan remitansi kepada tenaga kerja Indonesia maupun tata cara pengiriman remitansi secara legal karena seperti yang diketahui masih banyak PMI yang mengirim uang ke Indonesia secara ilegal dan kurangnya pengetahuan terkait outlet cash-in dan cash-out, sehingga remitansi diharapkan dapat memberikan manfaat yang jauh lebih besar terhadap pertumbuhan ekonomi. Beberapa strategi kebijakan yang dapat dipertimbangkan untuk meningkatkan pertumbuhan ekonomi melalui penanaman modal asing di Indonesia salah satunya berkaitan dengan upaya untuk memelihara kesinambungan pembangunan, maka dari itu perlu untuk menjadikan investasi asing langsung untuk meningkatkan jumlah investasi di Indonesia. Pemerintah perlu untuk meningkatkan jumlah investasi melalui peningkatan pengeluaran investasi pemerintah serta perbaikan infrastruktur dan berbagai kebijakan yang dapat menstimulus investor sehingga dapat membantu dalam menopang perekonomian Indonesia ke arah yang lebih stabil.

\section{REFERENSI}

Azoulay, P., Jones, B.F., Kim, J.D. and Miranda, J., 2020. Age and high-growth entrepreneurship. American Economic Review: Insights, 2(1), 65-8.

Badan Perlindungan Pekerja Migran Indonesia (BP2MI). (2020). Data Perkembangan Pekerja Migran Indonesia. Diakses melalui https://bp2mi.go.id/statistik-penempatan pada 20 Pebruari 2021.

Badan Pusat Statistik. (2020). Data PDB 2013-2020 Indonesia. Diakses melalui https://www.bps.go.id/publication.html pada 15 Januari 2021.

Bank Indonesia. (2019). Publikasi Laporan Tahunan Bank Indonesia. https://www.bi.go.id/id/publikasi/laporantahunan/bi/Default aspx pada 12 oktober 2020.

Bank Indonesia. (2020). LAPORAN PEREKONOMIAN INDONESIA 2020. Diakses melalui https://www.bi.go.id/id/publikasi/laporan/Documents/LPI_2020.pdf pada 20 juli 2021.

Pengaruh Remitansi, Foreign Direct Investment, dan Inflasi Terhadap Pertumbuhan Ekonomi Indonesia, Devi Natalia Kirana dan Anak Agung Ketut Ayuningsasi 
Barajas, A., Chami, R., Fullenkamp, C., Gapen, M., \& Montiel, P. J. (2009). Do workers' remittances promote economic growth? IMF Working Papers, 09(153), 1. https://doi.org/10.5089/9781451873009.001.

Bick, A. (2010). Threshold effects of inflation on economic growth in developing countries. Economics Letters, 108(2), 126-129.

Chami, R., Montiel, P., Barajas, A., \& Fullenkamp, C. (2009). Do Workers' Remittances Promote Economic Growth? IMF Working Papers, 09(153), 1. https://doi.org/10.5089/9781451873009.001.

Dama, H. Y., Lapian, A. L. C., \& Sumual, J. I. (2016). Pengaruh Produk Domestik Regional Bruto (PDRB) Terhadap Tingkat Kemiskinan Di Kota Manado (Tahun 2005-2014). Jurnal Berkala Ilmiah Efisiensi, 16(3), 549-561.

Dewi, E., Amar, S., \& Sofyan, E. (2013). Analisis Pertumbuhan Ekonomi, Investasi, dan Konsumsi di Indonesia. Jurnal Kajian Ekonomi, I(02), 176-193.

Dwi Kurniawan, Muhammad, D. (2020). Remitansi dan Pertumbuhan Ekonomi(Doctoral dissertation, Universitas Andalas).

Handoyo, R. D., Erlando, A., \& Septiya nto, I. (2020). Dampak Faktor Eksternal Terhadap Pertumbuhan Ekonomi Indonesia. Ecces (Economics, Social, and Development Studies), 7(1), 1. https://doi.org/10.24252/ecc.v7i1.13382

Kasidi, Faraji. (2013). Impact of Inflation on Economic Growth: A Ca se Study of Kanzania. Asian Journal of EmpiricalResearch13(4):363-380.

Kha ironi, L. M. (2019). Pengaruh Pengangguran dan Inflasi Terhadap Pertumbuhan Ekonomi di Provinsi Aceh. UIN Ar-Ra niry.

Kurniawan, R., \& Managi, S. (2018). Economic Growth and Sustainable Development in Indonesia: An Assessment. Bulletin of Indonesian Economic Studies, 54(3), 339-361. https://doi.org/10.1080/00074918.2018.1450962

Lincoln, E. J. (2004). East Asian economic regionalism. Wa shington DC: Brookings Institution Press.

Mankiw, N. G. (2014). Pengantar Ekonomi Mikro Edisi Asia. Jakarta: Sa lemba Empat.

Menteri Ketenagakerjaan Republik Indonesia. (2015). Keputusan Menteri Tenaga Kerja Nomor 260 Tahun 2015 tentang penghentian dan pelarangan penempatan TKI pada pengguna perseorangan di negara-negara kawasan Timur Tengah. Diakses melalui tps://kemlu.go.id/download/L1NoYXJ1ZCUyMERvY3VtZW50cy9LZXBtZW5ha2VyJTIwUkklMjBO b21vMiUyMDI2MCUyMFRhaHVuJTIwMjAxNS5wZGY= pada $20 \mathrm{Juli} 2021$.

Meyer, D., \& Shera, A. (2017). The impact of remittances on economic growth: An econometric model. Economia, 18(2), 147-155. https://doi.org/10.1016/j.econ.2016.06.001.

Ningsih, D., \& Andiny, P. (2018). Ana lisis Pengaruh Inflasi dan Pertumbuhan Ekonomi Terhadap Kemiskinan di Indonesia. Jurnal Samudra Ekonomika, 2(1), 53-61.

Pardede, V. N., \& Setyari, N. P. W. (2016). Pengaruh Remitansi Tenaga Kerja Indonesia Terhadap Kurs Dollar Amerika Tahun 2007-2016. E-Jurnal EP Unud, 7(9), 1826-1858. https://ojs.unud.ac.id/index.php/eep/article/view/40324.

Prabowo, Yulhan Rinto. (2018). Dampak Remitansi Tenaga Kerja terhadap Pertumbuhan Ekonomi di Indonesia.Fakultas Ekonomi, Skripsi. Universitas Negeri Yogyakarta.

Pra wira, B., Sarfiah, S. N., \& Jalunggono, G. (2019). Pen garuh Foreign Direct Investment (Fdi), Ekspor Dan Impor Terha dap Pertumbuhan Ekonomi Indonesia 1998-2017. DINAMIC: Directory Journal of Economic, 1(1), $1-10$.

Simanungkalit, Erika. 2020. Pengaruh Inflasi terhadap Pertumbuhan Ekonomi di Indonesia. Journal of Management, 13 (3): 327-340.

$\mathrm{Su}$, Yaqin and Liu, Zhiqiang, 2016. The Impact of Foreign Direct Investment and Human Capitalon Economic Growth : Evidence from ChineseCities. China Economic Review, 37(C), pp. 97-109.

Sukirno, S. (2011). Makro Ekonomi Teori Pengantar. Jakarta: PT. Ra jagrafindo Persada

Sulistiawati, R. (2012). Pengaruh investasi terhadap pertumbuhan Ekonomi dan penyerapan tenaga kerja serta kesejahteraan masyarakat di Provinsi di Indonesia. Jurnal ekonomi bisnis dan kewirausahaan, 3(1), 2950 .

Pengaruh Remitansi, Foreign Direct Investment, dan Inflasi Terhadap Pertumbuhan Ekonomi Indonesia, Devi Natalia Kirana dan Anak Agung Ketut Ayuningsasi 
Susic, I., Stojanovic-Trivanovic, M., \& Susic, M. (2017). Foreign direct investments and their impact on the economic development of Bosnia and Herzegovina. IOP Conference Series: Materials Science and Engineering, 200(1), 1-20. https://doi.org/10.1088/1757-899X/200/1/012019.

World Bank. (2020). Data FDI Indonesia. Diakses melalui https://data.worldbank.org/indicator/BX.KLT.DINV.CD.WD. Pada 12 Oktober 2020.

(2020). Laporan GDP konstan Indonesia. Diakses melalui https://data.worldbank.org/indicator/NY.GDP.MKTP.KD?locations=ID pada 15 Oktober 2020.

Pengaruh Remitansi, Foreign Direct Investment, dan Inflasi Terhadap Pertumbuhan Ekonomi Indonesia, Devi Natalia Kirana dan Anak Agung Ketut Ayuningsasi 